\title{
alpha ille
}

\section{The 2014 Atlanta Film Festival (ATLFF) \\ Atlanta, GA, U.S.A., 26 March-4 April 2014}

\section{A Report by Erin Lee Mock, University of West Georgia}

Given the meteoric rise of Georgia and Louisiana's film production in the last decade-a phenomenon dubbed "Hollywood South"- the Atlanta Film Festival has the potential to transcend its regional status, elevating itself to Tribeca-level prestige in the decade to come. Executive director Chris Escobar is clearly aware of the festival's potential and each of his decisions seem calculated to raise its profile, but, just as importantly, to make it unique among the world's ever-growing festival slate. These are worthy goals and an admirable approach.

Two impulses battle for the soul of the ATLFF and, many have argued, the city of Atlanta itself (see Tepper and Goodson). Atlantans have long had to reconcile its cosmopolitan history (and present) with its quintessential American Southernness. The Atlanta Film Festival sets itself apart by emphasising vibe over polish and variety over brand, so it would be false to claim that a particular theme or overarching vision guided the selection of films, except perhaps to answer the question: how to position a film festival in Atlanta, among the fastest-growing regional film cultures in the U.S. and worldwide? ${ }^{1}$ How to make a film festival that is indeed Atlantan?

Though Atlanta shows up more and more frequently on the small screen, there is still a relative dearth of images of the city in movie theatres. The same could be said for much of the American South. While the usual suspects-New York, Los Angeles, London-were certainly represented at the festival, it was refreshing to see new cinematic landscapes and locations and the individuals that populate these. There is no substitute for seeing one's own world reflected (or refracted) on film and the local audience responded passionately to films that showed them familiar surroundings and people who resembled them.

While not beloved by critics, David Gordon Green's Joe (2013) was an ideal openingnight selection for this reason. Written and directed by American Southerners and based on a novel by Larry Brown, a respected though not canonical Southern writer, the film feels authentically Southern, and not just because of its landscape. Nicholas Cage's Joe is a masculine archetype: the man who has proven himself capable of violence, who struggles against it, and who ultimately finds its utility for justice. Joe is, however, a richer character because of his Southernness. Scenes involving Joe and his black employees, Joe and his interracial extended family, Joe and the local chief of police, and between the film's white villain and one of his 
many victims (this victim was black), quietly argue that race relations in the South are more complex and subtle than those outside the American South likely assume. The screenplay and performances are thick with the dark humour and melodrama for which Southern literature is known.

The particular character of the American South figures significantly in other films as well. Juli Jackson's beautifully shot and moving drama 45RPM (2012) takes advantage of the Southern landscape more than any of the films in the festival, making the roads of the South a proving ground for two very different Southern characters. Like Green, Jackson also explores the sound textures of the South, especially its dynamic range. Pitched more consistently high, Limo Ride (Gideon C. Kennedy and Marcus Rosentrater, 2014), an ingenious "docu-comedy", effectively blends the Southern "raconteur" tradition with a surprisingly postmodern take on authenticity and film narrative. Limo Ride, one might say, defines "Southern American truth"in the tradition of the "yarn" - as rather different from "truth" as we generally understand it. This outlandishness is to its credit.

Of course, while more traditional documentaries may be less "formally" Southern, they effectively record the South's history and feeling. Few would argue that the South does not have purchase on much of major American music and two smart but heartfelt documentaries show slivers of this history. Lily Keber's Bayou Maharajah: The Tragic Genius of James Booker (2013) is the story of a world-class musician and the ways in which his life and career were coloured by his race, sexual orientation, and disability. Booker's Southern roots had as much to do with his music and performance style as these three aspects of his life, and the film effortlessly makes that obvious. The Winding Stream (Beth Harrington, 2014) examines the roots and country music scene as well, offering a fuller picture of twentieth-century music in the region. Both films also acknowledge how national and even global these musical forms have become.

Many filmgoers, Southern-American or not, associate American Southern regional identity with an abiding sense of the past. Joe feels like it could have taken place just about any time in the last hundred years and the documentaries, of course, focus on history itself. Limo Ride and 45RPM are far from formally old-fashioned, but both films are about nostalgia of a kind: to find one's self (or make one's self) is to look backward. However, not all of the Southern-made films in the Atlanta Film Festival felt nostalgic or, for that matter, particularly Southern. Atlanta filmmaker Alex Orr's sophomore effort, A is for Alex (2013), was a particular treat. With a post-mumblecore sensibility right out of Austin/Brooklyn/Portland, Orr's loose, weird humour and savvy sentimentality proved that Atlanta too has its hipster scene and is, if Orr is representative, the better for it. Orr's film does not imagine the past, but shows how very odd and even silly it is to try to imagine the future and to avoid imagining it.

There is a danger, though, to privileging "local" films and this was nowhere more apparent than in the hype around the mediocre Beside Still Waters (2013), Atlanta-native Chris Lowell's directorial debut. A sort of depoliticised remake of The Big Chill (Lawrence Kasdan, 1983) seems to have developed into a mini genre - these films tour the festival circuit and land quickly on Netflix; Beside Still Waters is, at best, a bland example of such. The q and a that 
followed the screening devolved into an ever-narrowing spiral of inside jokes, as the audience was composed mostly of family and friends. Had this film been an "underdog" of sorts, this homely display may have been welcome, but because it involved a swath of Hollywood actors and writers, a few of whom just so happen to be Atlanta-born, the self-indulgence was ridiculous.

Such missteps were rare and all festivals have them. In contrast to the monstrous slates of mediocrity at many higher profile festivals, the ATLFF's curation was careful and smart. The Pink Peach film series and the shorts programmes stood out: sometimes the smaller themed series suffer from diversity at the expense quality. Not so at the ATLFF.

The Pink Peach series of LGBTQ-themed films felt necessary and profound in comparison to many LGBTQ-themed series in other festivals. While LGBTQ rights remain in global crisis, it rarely feels that way at the major U.S. and Western European festivals, many of which inhabit pockets of relative (always relative) inclusivity. The state of Georgia is among the most legislatively anti-LGBTQ in the U.S.: LGBTQ Georgians are not protected against employment or other discrimination, Georgia is one of only five U.S. states without hate crime laws, and the state is at the back of the line on the issue of marriage equality, lacking even statewide legal domestic partnerships, with few signs of same-sex marriage or even civil unions on the immediate horizon. However, the ATLFF organisers successfully suppressed any impulse to simplify the lives of LGBTQ individuals in service of a political agenda. Though Queens and Cowboys: A Straight Year on the Gay Rodeo (Matt Livadary, 2014), The Foxy Merkins (Madeline Olnek, 2013) and Lucky (Laura Checkoway, 2013) all impressed me, Exposed (2013), Beth B's documentary about neoburlesque is nothing short of thrilling. A roller coaster of joy and pain, it exposes the lives of artists who are heroic in vulnerability and unparalleled in creativity.

While it is a cliché that the shorts programmes are the most important part of any film festival, there's truth to it: being a captive audience with narrowed choices is part of what makes festival-going special and shorts programmes take this experience furthest. With several shorts slates, curator Christina Humphreys culled variety and quality. Humphreys's perspective was in keeping with the festival's: she created programmes which highlighted the South in moments, but which positioned Southern films confidently alongside films from around the world. Two partly international selections-Josh Gibson's documentary Nile Perch (coproduced in Uganda and the U.S.) and Jordan Schiele's narrative $5 \mathrm{~cm}$ (produced in China) - are visually stunning and particularly memorable.

Unlike many film festivals, the ATLFF does not claim in its title to be "International", though it certainly could. Some of the best feature-length films on their schedule were made outside of the U.S., including the brilliant German drama Nothing Bad Can Happen (Tore Tanzt, Katrin Gebbe, 2013), arguably the most controversial film at Cannes last year. Gebbe's film explores the dark sides both of religious faith and of secularism when pushed to extremes, and is a film that Southern writer Flannery O'Connor and German-born filmmaker Michael Haneke should love. 
To further complicate any knee-jerk regional binary, the ATLFF featured Steven Knight's remarkable Locke (2013) near the mid-point of the festival and Richard Ayoade's creepy The Double (2013) for its closing night event. Though both filmmakers are British, their films exist in liminal space, not rural and not urban, not recognisable. Though we know where Locke's title character is going and where he left, all but the first two minutes of the film take place on a freeway at night, which looks like nearly any freeway at night. The world of The Double may be in the future, but it also registers the past with props and costumes from several different eras. It may be the United States or Britain, but it may not be either. Both films are grounded by the inner lives of their protagonists; audiences are to connect with individuals in crisis, rather than to a place or historical moment. In a festival filled with globe-spanning images and Southern American peculiarities, these (and other less-hyped films) proved that the ATLFF wants viewers to experience the breadth of what cinema can do and that the city of Atlanta is a place where they can do just that.

\section{Note}

${ }^{1}$ For more on the growth of the film industry in the American South, see Mansour.

\section{Works Cited}

A is for Alex. Dir. Alex Orr. Fake Wood Wallpaper, 2014. Film.

Bayou Maharajah: The Tragic Genius of James Booker. Dir. Lily Keber. Mairzy Doats Productions, 2013. Film.

Beside Still Waters. Dir. Chris Lowell. Storyboard Entertainment, 2013. Film.

The Big Chill. Dir. Lawrence Kasdan. Columbia Pictures, 1983. Film.

Brown, Larry. Joe. Chapel Hill, NC: Algonquin Books, 2003. Print.

The Double. Dir. Richard Ayodade. Alcove Entertainment, 2013. Film.

Exposed. Dir. Beth B. Schulberg Productions, 2013. Film.

5cm. Dir. Jordan Schiele. 2013. Film.

45RPM. Dir. Juli Jackson. Ozark Foothills Film Festival Productions, 2012. Film.

The Foxy Merkins. Dir. Madeline Olnek. 2013. Film. 
Goodson, Steven. Highbrows, Hillbillies, and Hellfire: Public Entertainment in Atlanta. Athens, GA: U. of Georgia P., 2007. Print.

Joe. Dir. David Gordon Green. Worldview Entertainment, 2013. Film.

Limo Ride. Dir. Gideon C. Kennedy, Marcus Rosentrater. Climenole and Top of the Bay Entertainment, 2014. Film.

Locke. Dir. Steven Knight. Shoebox Films, IM Global, 2013. Film.

Lucky. Dir. Laura Checkoway. 2013. Film.

Mansour, Iris. "The Next Big Hotspot for Making Movies Is Not New York or Hollywood". PolicyMic, 14 May 2014. Web. 11 June 2014. <http://www.policymic.com/articles/89355/thenext-big-hotspot-for-making-movies-is-not-new-york-or-hollywood>.

Nile Perch. Dir. Josh Gibson. 2013. Film.

Nothing Bad Can Happen [Tore Tanzt]. Dir. Katrin Gebbe. Junafilm. 2013. Film.

Queens and Cowboys: A Straight Year on the Gay Rodeo. Dir. Matt Livadary. 2014. Film.

Tepper, Stephen J. "Fast Times in Atlanta: Change, Identity, and Protest". Not Here, Not Now, Not That! Protest Over Art and Culture in America. Chicago: U. of Chicago P., 2011: 105-120. Print.

The Winding Stream. Dir. Beth Harrington. Beth Harrington Productions, 2014. Film.

\section{Suggested Citation}

Mock, Erin Lee. "The 2014 Atlanta Film Festival (ATLFF)". Festival report. Alphaville: Journal of Film and Screen Media 7 (Summer 2014). Web. ISSN: 2009-4078.

Erin Lee Mock is Assistant Professor of English and Director of the Programme in Film Studies at the University of West Georgia. Her work has appeared recently in Film and History, Camera Obscura, and an anthology about Golden-Age Westerns. Her research interests include postwar Hollywood and masculinity studies. 